\title{
Amino- and Diamino-9,10-Anthracenedione Derivatives: Biofocus and Applied Advantages - A Mini-Review
}

\author{
Maryna Stasevych 1,*(D), Viktor Zvarych 1(D), Marianna Barus ${ }^{2}$ (D) , Mykhailo Bratenko 2 (D) \\ 1 Department of Technology of Biologically Active Substances, Pharmacy, and Biotechnology, Lviv Polytechnic National \\ University, 79013 Lviv, Ukraine; maryna.v.stasevych@lpnu.ua (M.S.); \\ 2 Department of Medical and Pharmaceutical Chemistry, Bukovinian State Medical University, 58000 Chernivtsi, Ukraine \\ * Correspondence: maryna.v.stasevych@lpnu.ua;
}

Scopus Author ID 8636372500

Received: 25.01.2021; Revised: 28.02.2021; Accepted: 2.03.2021; Published: 6.03.2021

\begin{abstract}
Anthracenediones an important class among quinonic compounds of natural and synthetic origin with many applications. Amino- and diaminosubstituted 9,10-anthracenediones are one of the main classes among 9,10-anthracenedione derivatives. Primarily, they are the key structures for obtaining various dyes. Besides applying their dye properties, aminoanthracenediones became the objects for searching for new biologically active compounds with antibacterial, antifungal, anticancer, antioxidant, antiviral, immunostimulating, and antiprotozoal activity in medical chemistry. However, amino- and diamino-substituted 9,10-anthracenediones are widely used as analytical reagents, color, and metal indicators. Areas of the practical application of these compounds are constantly expanding. This mini-review dedicates the advantages of amino- and diamino-9,10-anthracenediones derivatives as biologically active compounds and substances with applied application in various fields.
\end{abstract}

Keywords: amino- and diamino-9,10-anthracenedione derivatives; antimicrobial activity; anticancer activity; antiviral activity; antiplatelet activity; applied advantages.

(C) 2021 by the authors. This article is an open-access article distributed under the terms and conditions of the Creative Commons Attribution (CC BY) license (https://creativecommons.org/licenses/by/4.0/).

\section{Introduction}

The widespread application of 9,10-anthcenedione derivatives and the peculiarity of their properties attract the attention of specialists and researchers in various fields of science and technology. This is evidenced by hundreds of publications that are published annually in scientific and patent literature. Amino- and diamino derivatives occupy one of the main places among 9,10-anthracenedione derivatives, and they are key compounds in the synthesis of a number of dyes, pigments, and phosphors. However, in addition to the traditional using of these compounds' coloring properties, they gradually became objects for several studies their pharmacological studies. The discovery of antitumor properties for several diamino-9,10anthracenediones and introducing the drug Mitoxantrone into medical practice was the impetus. Various amino- and aminohydroxyanthracenediones are also used as analytical reagents for photometric determination of different ions of metals, color reactions, metal indicators in complexometric titration. Many works are devoted to using amino and diaminopohydric 9,10-anthracenediones for the preparation of dyes [1]. There are several reviews on the antitumor activity of 9,10-anthracenedione derivatives [2-5]. However, there is no generalized review of the biological properties and applications of the amino derivatives of 9,10 -anthracenedione. Therefore, this mini-review will focus on coverage and compilation of 
results on the advantages of amino- and diamino-9,10-anthraquinone derivatives as biologically active compounds and substances with applied application in various fields.

\section{Amino-9,10-anthraquinones and their Derivatives as Biologically Active Substances}

The ability to bind to the estrogen $\alpha$-receptor (ERR $\alpha$ ) was found for 1(2)-amino- 1, 2, 1,4 (1,5)-diamino- 3, 4 (Fig. 1), 1-amino-2 (4/2,4)-halogen-substituted 9,10-anthracenediones [6]. 2-Aminoanthraquinone 2 , due to its ability to inhibit glutathione reductase, has been identified as a potential antimalarial substance [7], as an inhibitor of xanthine oxidase [8] and bacterial collagenase [9], as well as a suppressor of the formation of sulfides by sulfatereductive bacteria in wastewater [10,11], wells, process tanks for biomass fermentation [12]. 1,4-Diamino-9,10-anthracendione 3 and its derivatives showed positive results on the fixation of lactate dehydrogenase [13].<smiles>Nc1cccc2c1C(=O)c1ccccc1C2=O</smiles>

1<smiles>Nc1ccc2c(c1)C(=O)c1ccccc1C2=O</smiles>

2<smiles>Nc1ccc(N)c2c1C(=O)c1ccccc1C2=O</smiles>

3<smiles>Nc1cccc2c1C(=O)c1cccc(N)c1C2=O</smiles>

4

Figure 1. Mono- and diaminoanthraquinones in the biological application.

Several $N$-[(2-(2-acetamido-6-R-benzothiazol-2-yl]-1-amino-9,10-anthracenediones 5 showed in vitro experiments a fairly high antibacterial activity against bacteria Streptococcuss pneumoniae, Enterococcus faecalis, Salmonella typhi, Acinetobacte sp. [14]. The compounds with the ability to inhibit the growth of bacterial strains Staphylococcus aureus, Mycobacterium luteum and fungi Candida tenuis, Aspergillus niger were identified among the amino acid derivatives of 2-[chloro- $N$-(9,10-dioxo-9,10-dihydroanthracen-1-yl)acetamide 6 [15] and 2dithiocarbamate- $N$-(9,10-dioxo-9,10-dihydroanthracenyl)acetamides 7 [16] (Fig.1). The inhibitory effect on the growth of bacterial strains Bacillus subtilis, Bacillus cereus, Acinetobacter johnsonii, Sarcina lutea, Xanthomonas oryzae and fungus Saccharomyces cerevisiae, Candida lipolytica was found for the pyridine salt of 2-[chloro- $N$-(9,10-dioxo-9,10dihydroanthracen-2-yl)acetamide 8 [17].

The compounds with high indices of biological action against strains of gram-positive bacteria Staphylococcus aureus, Enterococcus faecium, Bacillus subtilis and the fungus Candida albicans, Aspirgillus niger, Trichophyton mentagrophytes were found among $\beta$ lactam derivatives 9 obtained based on 2-amino-9,10-dioxoanthracene [18]. The effective antistaphylococcal agents against strains Staphylococcus aureus ATCC 25923 та Staphylococcus aureus ATCC 29213 were found among anthra[1,2-d][1,2,3]triazine-4,7,12(3H)-triones 10 (Fig. 2) [19]. The compounds with selective antibacterial activity against Staphylococcus aureus, Escherichia coli, Bacillus subtilis, and antifungal effect against Alternaria alternata were found in a series of oxadiazole and azole derivatives of 9,10-anthracenedione [20]. 
<smiles>[R]c1ccc2sc(NC(=O)CNc3cccc4c3C(=O)c3ccccc3C4=O)nc2c1</smiles><smiles>[R]C(=O)NCC(=O)Nc1cccc2c1C(=O)c1ccccc1C2=O</smiles><smiles>[R]N([R])C(=S)SCC(=O)NCCc1cccc(C(=O)c2ccccc2C)c1</smiles><smiles>O=C(C[n+]1ccccc1)Nc1ccc2c(c1)C(=O)c1ccccc1C2=O</smiles>

8<smiles>[R]C1C(=O)N(c2cccc3c2C(=O)c2ccccc2C3=O)C1[R]</smiles>

9<smiles>[R]c1cc2c(=O)n([R1])nnc2c2c1C(=O)c1ccccc1C2=O</smiles>

10

Figure 2. Amino-9,10-anthraquinone derivatives with antimicrobial activity.

Derivatives of 9,10-anthracenedione substituted with 1,5-bis(diethylaminoethyl)- and 2,6-bis(dimethylaminoacetylamino) fragments 11 (Fig. 3) showed antiviral activity against HIV-1 [21, 22]. 1-Amino-4-arylamino-9,10-anthracenediones can act as inhibitors of human cytomegavirus $H C M V$ [23, 24], and 1,2- and 1,4-bisadamantanylanthracenediones have been proposed as potential anti-influenza agents due to their ability to stimulate interferon production [25]. The derivatives with antiviral activity against herpes virus $H S V-2$ and EbsteinBarr virus in cell cultures Raji, B95-8 were found among the dithiocarbamates 9,10anthracenedione 12, 13 (Fig. 3), obtained by the coupling reaction of the diazonium salts of aminoanthracendiones with dithiocarboxylic acids [26].<smiles>[R]Nc1cccc2c1C(=O)c1cccc(N[R])c1C2=O</smiles>

$11 \mathrm{R}=\left(\mathrm{CH}_{2}\right)_{2} \mathrm{CH}_{2}-\mathrm{N} \longrightarrow \mathrm{X}, \mathrm{X}=\mathrm{CH}_{2}, \mathrm{O}$ $\left(\mathrm{CH}_{2}\right)_{2} \mathrm{~N}\left(\mathrm{CH}_{2} \mathrm{CH}_{3}\right)_{2},\left(\mathrm{CH}_{2}\right)_{3} \mathrm{~N}\left(\mathrm{CH}_{2} \mathrm{CH}_{3}\right)_{2}$

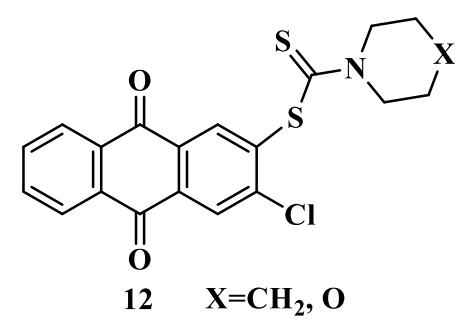

$12 \mathrm{X}=\mathrm{CH}_{2}, \mathrm{O}$<smiles>[R][NH2+]C1CCCN1C([R])=S</smiles>

Figure 3. Amino-9,10-anthraquinone derivatives with antiviral action.

In the same series of dithiocarbamate derivatives with 9,10-anthracenediones [27] obtained from 2-amino-9,10-anthracenediones, two compounds 14 and 15 (Fig. 4) with high antiaggregatory activity in in vitro experiments with IC $_{50}$ within $15-30 \mu \mathrm{m}$ for adenosine diphosphate-dependent aggregation and 10-20 $\mu \mathrm{m}$ for arachidonic acid-induced aggregation were found.<smiles>CCN(CC)C(=S)Sc1cc2c(cc1Cl)C(=[14CH2])c1ccccc1C2=O</smiles><smiles>O=C1c2ccccc2C(=O)c2cc(SC(=S)N3CCCCC3)c(Cl)cc21</smiles>

Figure 4. Amino-9,10-anthraquinone derivatives with the antiplatelet action 
The indicators of lipid peroxidation and oxidative modification of the protein were determined by studies of several amino acids and 2-iminothiazole derivatives of 9,10anthracenedione compounds 16-18 with antioxidant effect were found [28]. The hydrazone derivatives of 9,10-anthracenedione 19-21 (Fig. 5) with the highest antioxidant activity were determined by the CUPRAC method [29]. Also, 5-chloro-substituted 1-amino-9,10anthracenediones 22 with antioxidant effect were detected in work [30] by DPPH and ABTS.<smiles>CC(C)CC(NCC(=O)Nc1cccc2c1C(=O)c1ccccc1C2=O)C(=O)O</smiles>

16<smiles>CC(C)C(=O)NCC(=O)Nc1cccc2c1C(=O)c1ccccc1C2=O</smiles>

17<smiles>Cc1cs/c(=N\C(=O)c2ccccc2)n1-c1ccc(N)c2c1C(=O)c1ccccc1C2=O</smiles>

18<smiles>CC(=O)C=NNc1c(C(=O)O)ccc2c1C(=O)c1ccccc1C2=O</smiles>

19<smiles>CC1(C)CC(=O)C(=NNc2c(C(=O)O)ccc3c2C(=O)c2ccccc2C3=O)C(=O)C1</smiles>

20<smiles>O=C1NC(=O)C(=NNc2c(C(=O)O)ccc3c2C(=O)c2ccccc2C3=O)C(=O)N1</smiles>

21<smiles>CCOS(=O)(=O)c1cccc2c1C(=O)c1ccc(Cl)cc1C2=O</smiles>

22

Figure 5. Amino-9,10-anthraquinone derivatives with antioxidant effect.

Schiff bases obtained from 1-amino-9,10-anthracenedione have been proposed as a new type of analgesic substance [31]. The compounds with anti-inflammatory effects were found among derivatives 1(2)-amino-9,10-anthracenediones functionalized with carbocyclic moiety [32-36].

Derivative 23 with activity against Entamoeba histolytica was found among the bisamidines of 2,6-diamino-9,10-anthracenedione [37, 38]. Studies of an order of derivatives 24 allowed to classify 6-diacetaminoalkylenamines as agents with action against Trichomonas vaginalis, Trichomonasfetus тa Entamoeba histolytica (Fig. 6) [39].
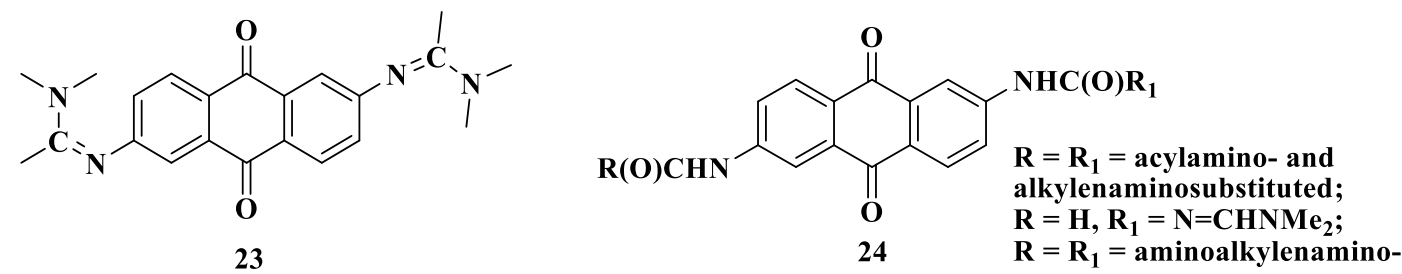

Figure 6. Amino-9,10-anthraquinone derivatives with antiprotozoic effect.

Besides the types mentioned above of pharmacological effects, special attention deserves derivatives 1(2)-amino-9,10-anthracenediones as an antineoplastic compound with a broad spectrum of activity against various types of cancer [3]. Mitoxantrone 25 and ametantrone 26 (Fig. 7) can be called the "progenitors" of the antitumor alkylamino-substituted 9,10 -anthracenediones. In particular, mitoxantrone is one of the most widely used and effective chemotherapeutic agents used in breast cancer treatment. It is also used to treat lymphoma, 
acute leukemia, chronic myelogenous leukemia, hepatocellular carcinoma [39]. In 2000, the drug was approved by the agency FDA (USA), has shown promising results in the treatment of multiple sclerosis [2] and acute disseminated encephalomyelitis [40]. Its analog pixantrone 27 is a licensed anticancer drug in Europe and is used as a monotherapeutic agent to treat aggressive resistant cases of non-Hodgkin's B-cell lymphoma (Fig. 7) [41].
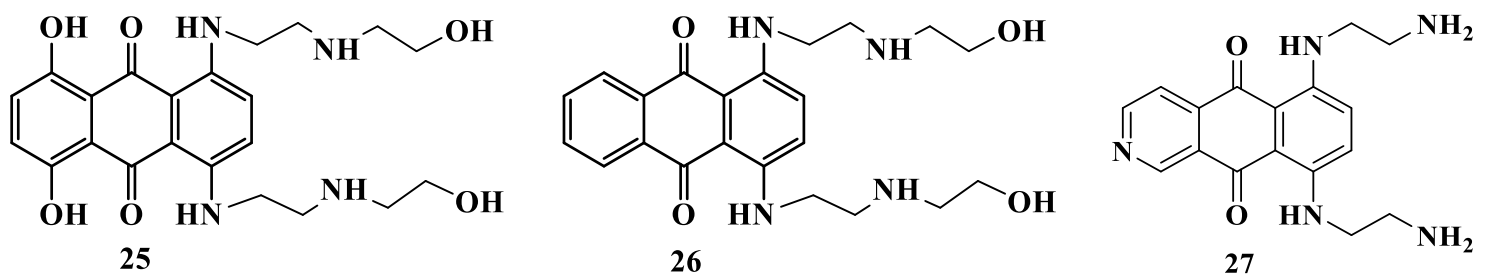

Figure 7. Amino-9,10-anthraquinone derivatives as anticancer drugs.

The discovery of several antitumor substances that are at different stages of preclinical testing was the result of successful structural modification of the following aminoanthracendiones: 1-aminoethylamino-, $\quad$ 1,4(1,5)-bis-(2-aminoethylamino)-, bis(oxyalkylamino)-, 1,5-bis/( $N, N$-dialkylamino)alkylamino/-9,10-anthracenediones and complexes of 1,4-bis(alkylamino)-5,8-dioxoanthracene-9,10-dione with metals [42-45]. In particular, such aminoanthracendiones NSC-639365 28, M-18 29, and Banoxantron 30 (Fig. 8) are in different phases of clinical trials [46].<smiles>CCNCC(O)CNc1ccc(NCC(O)CCl)c2c1C(=O)c1ccccc1C2=O</smiles>

28 NSC-639365<smiles>O=C1c2cc(Cl)c(Cl)cc2C(=O)c2c(NCCNCCO)ccc(NCCNCCO)c21</smiles>

$29 M-18$<smiles>C[N+](C)([O-])CCNc1ccc(NCC[N+](C)(C)[O-])c2c1C(=O)c1c(O)ccc(O)c1C2=O</smiles>

30 Banoxantron

Figure 8. Amino-9,10-anthraquinone derivatives in clinical investigations

Analysis of the data of the structure-activity dependence in a series of asymmetric derivatives of 1,2-diaminoanthracenedionivs allowed obtaining compounds of a new chemotype 31-34 with high cytotoxicity concerning the majority of NCI-60 cancer cell lines, which were patented (Fig. 9) [47].
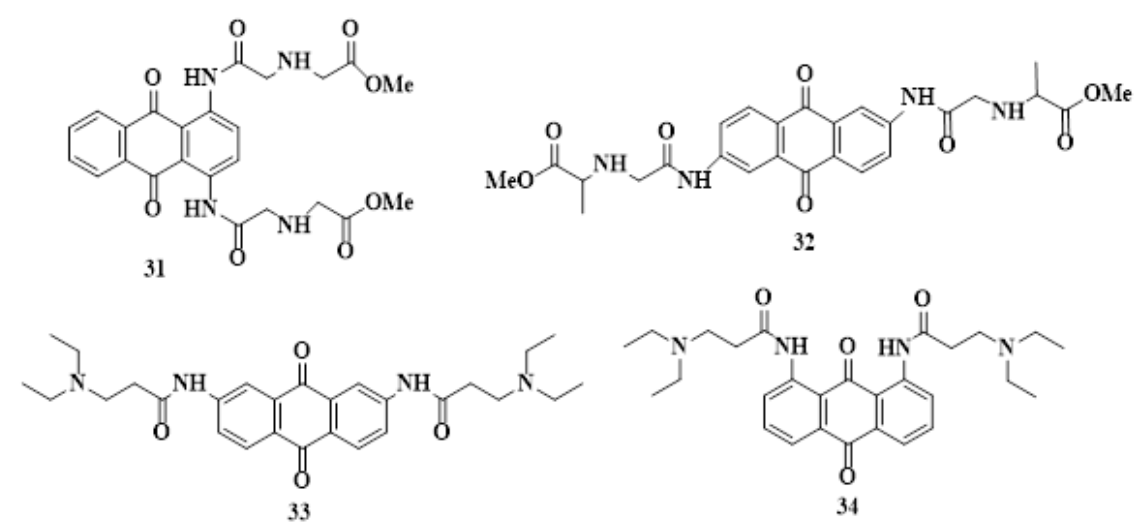

Figure 9. Amino-9,10-anthraquinone derivatives with anticancer activity. 
Antitumor compounds with immunostimulatory action were found among 3-amino-1,2alkoxy derivatives 35 [48], and for 1,8-diamino-3-methyl-9,10-anthracenedione and their $\mathrm{N}$ alkyl/aryl derivatives 36 radioprotective properties were found [49], which is important for radiation therapy (Fig. 10).<smiles>[R10]NCCOc1c(N)cc2c(c1OCCN([R1])[R1])C(=O)c1ccccc1C2=O</smiles><smiles>[R]Nc1cccc2c1C(=O)c1cc(C)cc(N[R])c1C2=O</smiles>

$36 \mathrm{R}=\mathrm{H}, \mathrm{Me}, \mathrm{Et}, \mathrm{Pr}, \mathrm{Bu}, \mathrm{Ph}, \mathrm{PhCO}$

Figure 10. Amino-9,10-anthraquinone derivatives with anticancer, immunostimulating, and radioprotective properties.

Generalized advances in the development of antitumor substances based on aminoanthracendiones in recent decades are presented in two reviews [2, 3].

The amino derivative of 9,10-anthracenedione with a 1,3,5-triazine moiety under the trade name Reactive Blue 237 (Fig. 11) has been found useful as a ligand in biochemical processes experimental pharmacology, and the development of new biologically active substances [2]. 9,10-Dioxoanthracenylamide derivative of ethacrynic acid 38 (Fig. 11) can act as an antagonist of $\mathrm{Wnt} / \beta$-catenin signaling and cell survival $C L L$ [50].<smiles>C=C(CC)C(=O)c1ccc(OCC(=O)Nc2ccc3c(c2)C(=O)c2ccccc2C3=O)c(Cl)c1Cl</smiles>

Figure 11. Amino-9,10-anthraquinone derivatives in biochemical processes.

Also, 1-amino- 1 and 2-amino-9,10-anthracenediones 2 are convenient promoters in the biotransformation of biphenol $F$ with the participation of Pseudomonas sp. HS-2 [51]. 1Amino-4-chloroanthracenedione, 1,4-diaminoanthracenedione, 1,5-diaminoanthracenedione, 1-amino-2-methylanthracenedione, 1-amino-2-carboxyanthracenedione, 1-amino-2chloroanthracenedione [52], and 1-amino-4-chloroanthracenedione [52, 53] were used as objects for the investigation of the biotransformation ability of Saccharopolyspora erythraea and Saccharothrix espanaensis, respectively.

\section{Applied Advantages of Amino-9,10-anthraquinones and their Derivatives}

Aminoanthracendiones and their derivatives occupy one of the main places in obtaining several dyes [1], which are widely used in various sectors of the industries.

A new fluorescent paper with enhanced fluorescent photoinduced electron transfer for $\mathrm{Mn}^{2+}, \mathrm{Cr}^{3+}$ Ta $\mathrm{F}^{-}$was proposed based on 1-amino-9,10-anthracenedione structurally combined with calix[4]arene [54]. 
2-Amino-9,10-anthracendione has been successfully used to produce a highly efficient supercapacitor electrode based on chemically modified graphene hydrogel [55] and in the production of ordered ensembles of organic and biological molecules on Au-bonded surfaces [56].

Graphene-anthracenedione composite surfaces with grafted plastic based on 1-amino2-bromo-4-hydroxy- and 2-amino-9,10-anthracenediones, have been patented as important agents in wastewater treatment polluted with azo dyes and nitrates [57]. A convenient method of dechlorination and biodegradation of 2-chloroanilines under anaerobic conditions was proposed using 2-amino-9,10-anthracenedione-graphene oxide composite [58]. 1,4-Bis( $p$ tolylamino)anthracene-9,10-dione was useful in obtaining a polymer for ophthalmic cosmetic purposes [59].

1-Amino-, 1-(methylamino)- and 1-(benzamido)-9,10-anthracenediones exhibited the properties of cationic photoinitiators of polymerization of epoxy monomers and divinyl ether under the influence of LEDs [60]. 1-Amino-4-hydroxy-, 1,4-diamino- and 1,5-diamino-9,10anthracenediones have been successfully used in multicolor photoinitiator systems [61].

The low-cost, safe flow-through battery system with stable charging and discharging cycles based on 1(2)-amine derivatives of 9,10-anthracendione has been patented [62]. 1,4-

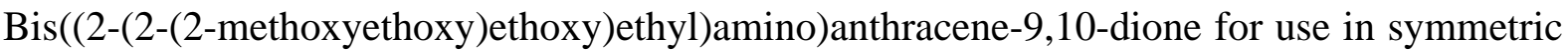
all-organic redox flow batteries that can store energy on a large scale without relying on critical raw materials [63].

The method of obtaining a conjugated redox poly- $N$-pyrrolylantracenedione polymer to obtain an aqueous all-organic hybrid-flow battery based on 9,10-dioxoanthracenyl-2-pyrrole obtained from 2-amino-9,10-anthracenedione [64] was carried out [65].

Also, photoinitiating systems for the free radical photopolymerization of various acrylate monomers and fast 3D printing under visible light were developed using 1-amino-4hydroxyanthraquinone, 1,4-diaminoanthraquinone, and 1,5-diaminoanthraquinone [66].

The supramolecular interaction of $\beta$-cyclodextrins and $N$-alkylaminoanthrcenedione was used to obtain self-assembly fluorescent vesicles as a new kind of fluorescence staining material for living cells, for example, the human breast cancer cells MCF-7 and mice mononuclear macrophages $R E W-264.7$ [67]. The obtained experimental data allowed to propose the plausible mechanism of the self-assembly fluorescent vesicles forming [67].

$N^{\prime}$-(9,10-Dioxo-9,10-dihydroanthracen-2-yl)-1-glycylpyrrolidine-2-carbohydrazide 39 was used as a new compound with fluorogenic properties for demonstration dipeptidyl peptidase IV(DPP IV) in the detection of the enzyme using the histochemical study (Fig. 12). [68].

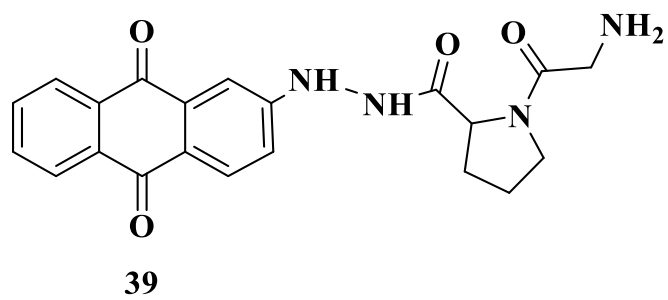

Figure 12. $N$-(9,10-Dioxo-9,10-dihydroanthracen-2-yl)-1-glycylpyrrolidine-2-carbohydrazide as fluorogenic compound for the histochemical DPP IV.

Amino- and diamino-9,10-anthracenedione derivatives 40-42 (Fig. 13) were utilized in an aromatic composition as dye components with aldehyde perfume component [69]. 

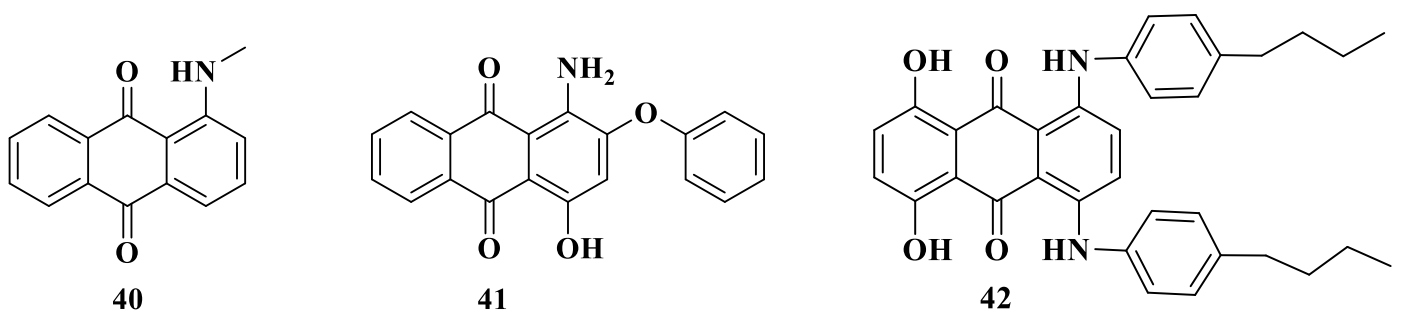

Figure 13. Amino- and diamino-9,10-anthracenedione derivatives as colorant component in an aromatic composition.

Moreover, amino derivatives of 9,10-anthracenedione 41, 43-46 (Fig. 14) found their application as a component of the dimethrin-containing carrier in the obtaining of the mosquitorepellent fibers with long-acting properties [70].<smiles>Cc1ccc(Nc2ccc(O)c3c2C(=O)c2ccccc2C3=[W])cc1</smiles><smiles></smiles><smiles>Cc1cc(C)c(Nc2ccc(Nc3c(C)cc(C)cc3C)c3c2C(=O)c2ccccc2C3=O)c(C)c1</smiles><smiles></smiles>

Figure 14. Amino- and diamino-9,10-antracenediones as components for preparation of mosquitorepellent fibers.

\section{Conclusions}

Amino- and diamino-9,10-anthracenediones and their derivatives are compounds with strong synthetic, pharmacological and practical potential, which do not lose their relevance to this day. They occupy one of the main places in obtaining several dyes, various reagents for analytical needs, organic chemosensors, and catalysts. Amino derivatives of 9,10dioxoanthracene have enriched the arsenal of biologically active substances, including compounds with antitumor, antiprotozoal, antiviral, antimicrobial, anti-inflammatory action. Some of them are known as antitumor drugs (mitoxantrone, ametantrone), which are widely used in world chemotherapeutic practice, and several derivatives are in the II and III phases of clinical trials. It should be noted that 1(2)-amino- and 1,4(1,5)-diamino-9,10-dioxoanthracenes are key substrates in obtaining almost all 9,10-anthracenedione dyes and pigments, as well as bioactive derivatives, in particular with antimicrobial and antitumor activity. Therefore, directed structural modification of amino groups of the 9,10-anthracenedione ring by various pharmacophore fragments remains the most interesting and promising direction among the production and study of new derivatives 9,10-anthracenedione, which is determined by the needs of both medical chemistries and applied using these class of compounds.

\section{Funding}

This research was funded by the Ministry of Education and Science of Ukraine, Project number: 0119U002252. 


\section{Acknowledgments}

This research has no acknowledgment.

\section{Conflicts of Interest}

The authors declare no conflict of interest.

\section{References}

1. Bien, H.-S.; Stawitz. J.; Wunderlich, K. Anthraquinone Dyes and Intermediates. In: Ullmann's Encyclopedia of Industrial Chemistry. 6th ed.; Kellersohn, T. Ed.; Wiley-VCH Verlag Gmbh: Weinheim 2003; pp. 513578.

2. Malik, E.M.; Muller, C.E. Anthraquinones as pharmacological tools and drugs. Med. Res. Rev. 2016, 36, 705-748, https://doi.org/10.1002/med.21391.

3. Tikhomirov, A.S.; Shtil, A.A.; Shchekotikhin, A.E. Advances in the discovery of anthraquinone-based anticancer agents. Recent Pat. Anti-Cancer Drug Discovery 2018, 13, 159-183, https://doi.org/10.2174/1574892813666171206123114.

4. Tian, W.; Wang, C.; Li, D.; Hou H. Novel anthraquinone compounds as anticancer agents and their potential mechanism. Future Medicinal Chemistr 2020, 12, 627-644, https://doi.org/10.4155/fmc-2019-0322.

5. Hussain, H.; Al-Harrasi, A.; Al-Rawahi, A.; Green, I.R.; Csuk, R.; Ahmed, I.; Shah, A.; Abbas, G.; Rehman, N.U.; Ullah R. A fruitful decade from 2005 to 2014 for anthraquinone patents. Expert Opin. Ther. Pat. 2015, 25, 1053-1064, https://doi.org/10.1517/13543776.2015.1050793.

6. Li, F.; Li, X.; Shao, J.; Chi, P.; Chen, J.; Wang, Z. Estrogenic activity of anthraquinone derivatives: in vitro and in silico studies. Chem. Res. Toxicol. 2010, 23, 1349-1355, https://doi.org/10.1021/tx100118g.

7. Lüönd, R.M.; McKie, J.H.; Douglas, K.T.; Dascombe, M.J.; Vale, J. Inhibitors of glutathione reductase as potential antimalarial drugs kinetic cooperativity and effect of dimethyl sulphoxide on inhibition kinetics. $J$. Enzyme Inhib. 1998, 13, 327-345, https://doi.org/10.3109/14756369809021479.

8. Rauf, A.; Khan, R.; Khan, H.; Jehan, N.; Akram, M.; Ahmad, Z.; Muhammad, N.; Farooq, U.; Khan, A. In vitro antimalarial and xanthine oxidase inhibition of 2-aminoanthraquinone. Pak. J. Pharm. Sci. 2016, 29, 429-432.

9. Tanaka, T.; Metori, K.; Satoshi, M.; Hitoshi, M. Studies on collagenase inhibitors. II. Inhibitory effects of anthraquinones on bacterial collagenase. Yakugaku Zasshi 1990, 110, 688-692, https://doi.org/10.1248/yakushi1947.110.9_688.

10. Weimer, P.J.; Odom, J.M.; Cooling, F.B.; Anderson, A.G. Anthraquinones as inhibitors of sulfide production from sulfate-reducing bacteria. US5385842 (A). 1995.

11. Tatnall, R.E. Finely divided anthraquinone formulations as inhibitors of sulfide production from sulfatereducing bacteria. US5500368. 1996.

12. Odom, J.M. Anthraquinone inhibition of methane production in methanogenic bacteria. US1994008738. 1994.

13. Campbell, M.E.; Mueller, J. Synthesis of 1,4-diaminoanthraquinones for the purification of lactate dehydrogenase. The FASEB Journal 2018, 32.

14. Khan, A.K.; Essa, H.J.; Al-Majidi, S.M.H. Synthesis, characterization and antimicrobial screening of new 1-aminoanthraquinone derivatives. Journal of Al-Nahrain University 2016, 19, 25-35, https://doi.org/10.22401/JNUS.19.1.03.

15. Zvarich, V.I.; Stasevich, M.V.; Stan'ko, O.V.; Komarovskaya-Porokhnyavets, E.Z.; Poroikov, V.V.; Rudik, A.V.; Lagunin, A.A.; Vovk, M.V.; Novikov, V.P. Computerized prediction, synthesis, and antimicrobial activity of new amino-acid derivatives of 2-chloro- $N$-(9,10-dioxo-9,10-dihydroanthracen-1-yl)acetamide. Pharm. Chem. J. 2014, 48, 584-588, https://doi.org/10.1007/s11094-014-1154-z.

16. Zvarych, V.; Stasevych, M.; Novikov, V.; Vovk, M. Synthesis and study of antimicrobial activity of 2dithiocarbamate- $N$-(9,10-dioxo-9,10-dihydroanthracenyl)acetamides. Biointerface Res. Appl. Chem. 2021, 11, 7725 - 7734, https://doi.org/10.33263/BRIAC111.77257734.

17. Yordanova, S.; Vasileva-Tonkova, E.; Staneva, D.; Stoyanov, S.; Grabchev, I. Synthesis and characterization of new water soluble 9,10-anthraquinone and evaluation of its antimicrobial activity. J. Mol. Struct 2018, 1168, 22-27, https://doi.org/10.1016/j.molstruc.2018.05.007.

18. Mohamadzadeh, M.; Zarei, M.; Vessal, M. Synthesis, in vitro biological evaluation and in silico molecular docking studies of novel $\beta$-lactam-anthraquinone hybrids. Bioorg. Chem. 2019, 95, https://doi.org/10.1016/j.bioorg.2019.103515.

19. Zvarych, V.; Stasevych, M.; Novikov, V.; Rusanov, E.; Vovk, M.; Szweda, P.; Grecka, K.; Milewski, S. Anthra[1,2- $d][1,2,3]$ triazine-4,7,12(3H)-triones as a new class of antistaphylococcal agents: synthesis and biological evaluation. Molecules 2019, 24, https://doi.org/10.3390/molecules24244581. 
20. Berghot, M.A.; Hanna, M.A.; Girges, M.M. Synthesis and biological activity of some heterocyclic systems containing anthraquinone. Die Pharmazie 1992, 47, 340-343.

21. Stringfellow, D.A.; Weed, S.D.; Underwood, G.E. Antiviral and interferon-inducing properties of 1,5diamino anthraquinones. antimicrob. Antimicrob. Agents Chemother 1979, 15, 111-118, https://doi.org/10.1128/aac.15.1.111.

22. Grisar, J.M.; Sill, A.D.; Fleming, R.W. Bis(aminoalkylsulfamoyl)anthraquinone antiviral agents. US3983248A. 1976.

23. Barnard, D.L.; Huffman, J.H.; Morris, J.L.B.; Wood, S.G.; Hughes, B.G.; Sidwell, R.W. Evaluation of the antiviral activity of anthraquinones, anthrones and anthraquinone derivatives against human cytomegalovirus. Antiviral Res. 1992, 17, 63-77, https://doi.org/10.1016/0166-3542(92)90091-i.

24. Alam, Z.; Al-Mahdi, Z.; Zhu, Y.; McKee, Z.; Parris, D.S.; Parikh, H.I.; Kellogg, G.E.; Kuchta, A.; McVoy, M.A. Anti-cytomegalovirus activity of the anthraquinone atanyl blue PRL. Antiviral Res. 2015, 114, 86-95, https://doi.org/10.1016/j.antiviral.2014.12.003.

25. Litvinova, L.A.; Lyakhov, S.A.; Andronati, S.A.; Zhukova, N.A.; Yasinskaya, O.G.; Galkin, B.N.; Filippova, T.O.; Golovenko, N.Y. Synthesis and pharmacological properties of new aminoacylaminoanthraquinones. Pharm. Chem. J. 1998, 32, 637-640, https://doi.org/10.1007/BF02641313.

26. Stasevich, M.V.; Zvarich, V.I.; Novikov, V.P.; Zagorodnyaya, S.D.; Povnitsa, O.Yu.; Chaika, M.A.; Nesterkina, M.V.; Kravchenko, I.A.; Druzhilovskii, D.S.; Poroikov, V.V. 9,10-Anthaquinone dithiocarbamates as promising pharmaceutical agents with pleiotropic action: computer prediction of biological activity and experimental validation. Pharm. Chem. J. 2020, 53, 905-913, https://doi.org/10.1007/s11094-020-02098-x.

27. Halenova, T.I.; Nikolaeva, I.V.; Stasevych, M.V.; Zvarych, V.I.; Lunin, V.V.; Novikov, V.P.; Savchuk, O.M. Platelet aggregation under the influence of some dithiocarbamate derivatives of 9,10-anthracenedione. Res. J. Pharm. Biol. Chem. Sci 2017, 8, 1626-1632.

28. Stasevych, M.V.; Zvarych, V.I.; Spreis, D.R.; Yaremkevych, O.S. Computer prediction and verification of antioxidative activity of exo-functionalized derivatives of 9,10-antraquinone. Chemistry, Technology and Application of Substances 2019, 2, 83-91, https://doi.org/10.23939/ctas2019.01.083.

29. Stasevych, M.; Zvarych, V.; Lunin, V.; Kopak, N.; Komarovska-Porokhnyavets, O.; Deniz, N.G.; Sayil, C.; Ozyurek, M.; Guclu, K.; Vovk, M.; Novikov, V. Synthesis, investigation of antimicrobial and antioxidant activity of anthraquinonylhydrazones. Monatsh. Chem 2018, 149, 1111-1119, https://doi.org/10.1007/s00706-018-2157-3.

30. Lakshman, S.; Murthy, Y.L.N.; Rao, K.R.M. Studies on synthesis and antioxidant property of anthraquinone analogues. Materials Today: Proceedings 2020, https://doi.org/10.1016/j.matpr.2020.03.719.

31. Fareed, G.; Rizwani, G. H.; Ahmed, M.; Versiani, M. A.; Fareed, N. Schiff bases derived from 1aminoanthraquinone: a new class of analgesic compounds. Pakistan Journal of Scientific and Industrial Research, Series A: Physical Sciences 2017, 60, 122-127.

32. Sondhi, S.M.; Sharma, V.K.; Singhal, N.; Verma, R.P.; Shukla, R.; Raghubir, R.; Dubey, M.P. Synthesis and anti-inflammatory activity evaluation of some acridinylaminoantipyrine, acridinylaminoanthraquinone, acridinothiourea and thiazolinothiourea derivatives. Phosphorus, Sulfur, Silicon Relat. Elem 2000, 156, 2133, https://doi.org/10.1080/10426500008044991

33. Sondhii, S.M.; Verma, R.P.; Singhal, N.; Sharma, V.K.; Shukla, R.; Patnaik, G.K. Antiinflammatory and analgesic activity evaluation of heterocyclic compounds synthesized by the reaction of 4-isothiocyanato-4methyl-2-pentanone with amines. Phosphorus, Sulfur, Silicon Relat. Elem 1996, 118, 7-19, https://doi.org/10.1080/10426509608038795

34. Salnikova, S.Y.; Ilyina, T.V.; Zhuravlev, N.C.; Verdyan, A.I. Synthesis and study of pharmacological activity of substituted amides of 2-anthraquinone succinamic acid. Pharm. Chem. J. 1990, 24, 204-406.

35. Singh, I.P.; Saxena, A.K.; Shanker, K. Newer indolylthiazolidinones as potent anti-inflammatory agents. Indian J. Chem., Sect. B: Org. Chem. Incl. Med. Chem. 1986, 25, 838-843.

36. Drogovoz, S.M .; Slishkov, V.V .; Rangel, S.E .; Bezugly, P.A .; Stefan, L.M .; Brigita N.V. Synthesis and pharmacological activity of anthraquinone malonamic acid derivatives. Pharmaceutical Journal 1992, 4, 43-47.

37. Fabio, P.F.; Fields, T.L.; Lin, Y.; Burden, E.J.; Carvajal, S.; Murdock, K.C.; Lang, S.A.Jr. Bisamidines of 2,6-diaminoanthraquinone as antiamebic agents. J. Med. Chem. 1978, 21, 273-276, https://doi.org/10.1021/jm00201a007.

38. Winkelmann, E.; Raetner, W. Chemotherapeutically active anthraquinones. I. Aminoanthraquinones. Arzneimittelforschung 1979, 29, 1504-1509.

39. Evison, B.J.; Sleebs, B.E.; Watson, K.G.; Phillips, D.R.; Cutts, S.M. Mitoxantrone, more than just another topoisomerase II poison. Medicinal research reviews 2016, 36, 248-299, https://doi.org/10.1002/med.21364.

40. Kerwar, S. S.; Sloboda, A. E.; Ridge, S. C. Method of treating multiple sclerosis. US000281. 1986.

41. Minotti, G.; Han, H.; Cattan, V.; Egorov, A.; Bertoni, F. Pixantrone: novel mode of action and clinical readouts. Expert Review of Hematology 2018, 11, 587-596, https://doi.org/10.1080/17474086.2018.1476848. 
42. Ishmael, D R. Anti-tumor compounds derived from 1,4,5,8-tetrachloroanthraquinone. US8420861. 2013.

43. Katzhendler, J.; Gean, K.-F.; Bar-Ad, G.; Tashma, Z.; Ben-Shoshan, R.; Ringel, I.; Buchrach, U.; Ramu, A. Synthesis of aminoanthraquinone derivatives and their in vitro evaluation as potential anticancer drugs. Eur. J. Med. Chem. 1989, 24, 23-30, https://doi.org/10.1016/0223-5234(89)90159-1.

44. Jiang, J. B.; Johnson, M.G. Bis-(hydroxylakylamino)-anthraquinone inhibitors of protein kinase C. US5344841. 1994.

45. Lang, S.A.; Murdock, K.C. Metal chelates of 1,4-bis(substituted-amino-5,8-dihydroxy-anthraquinones. US4296030A. 1981.

46. Thomson Reuters Integrity database. Available online: https://integrity.clarivate.com/integrity/xmlxsl/ (accessed December 14, 2020)

47. Huang, H.-S. Novel 1,2-disubstituted amido-anthraquinone derivatives, preparation method and application thereof. US8304415. 2012.

48. Litvinova, L.A.; Lempart, G.V.; Filippova, T.O.; Zhuk, O.V. Immunostimulants. II. Synthesis and immunotropic activity of some anthraquinone derivatives. Pharm. Chem. J. 1978, 12, 65-67.

49. Miyamoto, H. In vitro chemosensitivity and radiosensitivity of an adriamycin-resistant subline of human small cell lung cancer cells. Acta Medica Okayama 1986, 40, 75-81, https://doi.org/10.18926/AMO/31920.

50. Jin, G.; Lu, D.; Yao, S.; Wu, C.C.; Liu, J.X.; Carson, D.A.; Cottam, H.B. Amide derivatives of ethacrynic acid: synthesis and evaluation as antagonists of Wnt/beta-catenin signaling and CLL cell survival. Bioorg. Med. Chem. Lett. 2009, 19, 606-609, https://doi.org/10.1016/j.bmcl.2008.12.067.

51. Zhang, Q.; Lu, H.; Zhou, Y.; Wang, X.; Zhang, B. Anaerobic biotransformation of bisphenol F by Pseudomonas sp. HS-2 and promoted by hydrophobic anthraquinone compounds. Huanjing Kexue Xuebao 2019, 39, 2938-2944.

52. Gutacker, F.; Schmidt-Bohli, Y.-I.; Strobel, T.; Qiu, D.; Jessen, H.; Paululat, T.; Bechthold, A. Identification and Characterization of a Novel N- and O-Glycosyltransferase from Saccharopolyspora erythraea. Molecules 2020, 25, https://doi.org/10.3390/molecules25153400.

53. Strobel, T.; Schmidt, Y.; Linnenbrink, A.; Luzhetskyy, A.; Luzhetska, M.; Taguchi, T.; Brötz, E.; Paululat, T.; Stasevych, M.; Stanko, O.; Novikov, V.; Bechthold, A. Tracking down biotransformation to the genetic level: identification of a highly flexible glycosyltransferase from Saccharothrix espanaensis. Appl. Environ. Microbiol 2013, 79, 5224-5232, https://doi.org/10.1128/AEM.01652-13.

54. Sutariya, P.G.; Soni, H.; Gandhi, S.A.; Pandya, A. Novel luminescent paper based calix[4]arene chelation enhanced fluorescence- photoinduced electron transfer probe for $\mathrm{Mn}^{2+}, \mathrm{Cr}^{3+}$ and $\mathrm{F}^{-}$. J. Lumin. 2019, 208, 6-17, https://doi.org/10.1016/j.jlumin.2018.12.009.

55. Wu, Q.; Sun, Y.; Bai, H.; Shi, G. High-performance supercapacitor electrodes based on graphene hydrogels modified with 2-aminoanthraquinone moieties. Phys. Chem. Chem. Phys. 2011, 13, 11193-11198, https://doi.org/10.1039/c1cp20980a.

56. Zareie, H.; Sarikaya, M.; Mcdonagh, A.M.; Barber, J.; Cortie, M.; Phillips, M. Self-Organized Materials: From Organic molecules to Genetically Engineered Gold-Binding Proteins. In: International Conference on Nanoscience and Nanotechnology, Brisbane, Qld., Australia, July 3-7, 2006; pp. 517-519, https://doi.org/10.1109/ICONN.2006.340667.

57. Zeng, M.; Xu, M.; Yan, B.; Ye, Q.; Xu, S.; Liao, W. Graphene/anthraquinone compound composite surface grafted plastic, its preparation method and application in azo dye/nitrate-containing sewage treatment. China Patent CN110105586, 2019.

58. Lu, H.; Zhang, T.; Zhou, Y.; Zhou, J.; Wang, J.; Wang, X. Enhanced dechlorination and biodegradation of 2-chloroaniline by a 2-aminoanthraquinone-graphene oxide composite under anaerobic conditions. Sci. Rep. 2019, 9, https://doi.org/10.1038/s41598-019-48904-9.

59. Neefe, C.W. Fluorescent non-optical corneal color change device. US4615593. 1986.

60. Zhang, J.; Lalevee, J.; Hill, N.S.; Peng, X.; Zhu, D.; Kiehl, J.; Morlet-Savary, F.; Stenzel, M.H.; Coote, M.L.; Xiao, P. Photoinitiation mechanism and ability of monoamino-substituted anthraquinone derivatives as cationic photoinitiators of polymerization under LEDs. Macromol. Rapid Commun. 2019, 40, e1900234, https://doi.org/10.1002/marc.201900234

61. Zhang, J.; Lalevee, J.; Hill, N.S.; Launay, K.; Morlet-Savary, F.; Graff, B.; Stenzel, M.H.; Coote, M.L.; Xiao, P. Disubstituted aminoanthraquinone-based multicolor photoinitiators: photoinitiation mechanism and ability of cationic polymerization under blue, green, yellow, and red LEDs. Macromolecules 2018, 51, 81658173, https://doi.org/10.1021/acs.macromol.8b01763.

62. Chen, L.; Xu, J.; Han, J.; Wu, Y.; Su, Z.; Cui, Y.; Li, D. Flow battery system based on aminoanthraquinone derivatives. CN110444787. 2019.

63. Geysens, P.; Li, Y.; Vankelecom, I.; Fransaer, J.; Binnemans K. Highly Soluble 1,4-Diaminoanthraquinone Derivative for Nonaqueous Symmetric Redox Flow Batteries. ACS Sustainable Chem. Eng. 2020, 8, 38323843, https://doi.org/10.1021/acssuschemeng.9b07244.

64. Zvarych, V.I.; Stasevych, M.V.; Lunin, V.V.; Vovk, M.V.; Novikov, V.P. Synthesis of (1H-pyrrol-1yl)anthracene-9,10-diones. Chem. Heterocycl. Compd. 2016, 52, 421-423, https://doi.org/10.1007/s10593016-1904-9. 
65. Cao, J.; Ding, F.; Chen, H.; Wang, H.; Wang, W.; Chen, Z.; Xu, J. A new redox-active conjugated polymer containing anthraquinone pendants as anode material for aqueous all-organic hybrid-flow battery. J. Power Sources. 2019, 423, 316-322, https://doi.org/10.1016/j.jpowsour.2019.03.098.

66. Zhang, J.; Launay, K.; Hill, N.S.; Zhu, D.; Cox, N.; Langley, J.; Lalevée, J.; Stenzel, M.H.; Coote, M.L.; Xiao, P. Disubstituted Aminoanthraquinone-Based Photoinitiators for Free Radical Polymerization and Fast 3D Printing under Visible Light. Macromolecules 2018, 51, 10104-10112, https://doi.org/10.1021/acs.macromol.8b02145.

67. Sun, T.; Zhang, H.; Yan, H.; Li, J.; Cheng, G.; Hao, A.; Qiao, H.; Xin, F. Sensitive fluorescent vesicles based on the supramolecular inclusion of $\beta$-cyclodextrins withN-alkylamino-l-anthraquinone. Supramol. Chem. 2011, 23, 351-364, https://doi.org/10.1080/10610278.2010.514614.

68. Dikov, A.; Dimitrova, M.; Krieg, R.; Halbhuber, K.-J. New fluorescent method for the histochemical detection of dipeptidyl peptidase using glycyl-L-prolyl-2-anthraquinonyl hydrazide as substrate. Cell. Mol. Biol 2004, 50, OL553-OL558.

69. Keiki, K. Aromatic composition containing anthraquinone type dye component and aldehyde type perfume component. JP2018051283A. 2018.

70. Jing, L. Mosquito-repellent dyeing liquids for polyester fibers and preparation method thereof. CN106245148 A. 2016. 